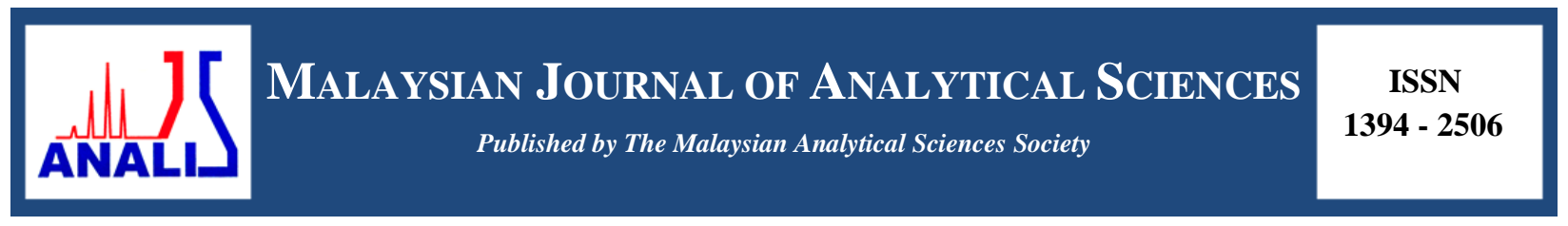

\title{
HYDROGEN SORPTION OF MAGNESIUM OXIDE CARBON NANOFIBRE COMPOSITE
}

\author{
(Serapan Hidrogen pada Komposit Magnesium Oksida Nano-gentian Karbon) \\ Nurul Zafirah Abd. Khalim Khafidz ${ }^{1}$, Zahira Yaakob ${ }^{1,2}$, Sharifah Najiha Timmiati ${ }^{1}$, Kuen-Song Lin ${ }^{3}$, \\ Kean Long $\operatorname{Lim}^{1} *$ \\ ${ }^{l}$ Fuel Cell Institute \\ ${ }^{2}$ Center for Sustainable Process Technology (CESPRO) \\ Universiti Kebangsaan Malaysia, 43600 UKM Bangi, Selangor, Malaysia \\ ${ }^{3}$ Department of Chemical Engineering and Materials Science, \\ Yuan Ze University, Chung-Li City 320, Taiwan \\ *Corresponding author: kllim@ukm.edu.my
}

Received: 13 April 2017; Accepted: 17 April 2018

\begin{abstract}
Carbon nanofibres have high specific surface area to adsorb hydrogen on their surface and are widely investigated for hydrogen storage. Although carbon nanofibres can store a considerable amount of hydrogen, the adsorption of the latter must be conducted at cryogenic conditions. Here, $\mathrm{MgO}$ is proposed as a catalyst to improve the hydrogen storage performance of carbon nanofibres at room temperature because of the light weight $\mathrm{MgO}$ and its ability to dissociate hydrogen molecules. The magnesium oxidecarbon nanofibre $(\mathrm{MgO}-\mathrm{CNF})$ composite was prepared with polivinylpyrrolidone polymer and $\mathrm{MgO}$ via an electrospinner. The samples were characterised with field emission scanning electron microscopy, X-ray diffraction, Fourier transform infrared spectroscopy, thermogravimetric analysis, differential scanning calorimetry and microgravimetric analysis. The MgO particles were formed on the surface and embedded inside the $\mathrm{MgO}-\mathrm{CNFs}$, thereby increasing the specific surface area. The assynthesised $\mathrm{MgO}-\mathrm{CNFs}$ with a specific surface area of $547 \mathrm{~m}^{2} / \mathrm{g}$ can store $2.54 \mathrm{wt} . \%$ of hydrogen at room temperature, showing more than $30 \%$ improvement as compared with that of CNFs.
\end{abstract}

Keywords: electrospinning, hydrogen storage, carbon nanofibre, metal oxide

\begin{abstract}
Abstrak
Nano-gentian karbon mempunyai kelebihan dengan luas permukaan yang tinggi untuk menjerap hidrogen di atas permukaan nano-gentian karbon, berpotensi sebagai bahan penyimpanan hidrogen. Walaupun nano-gentian karbon mempunyai kebolehan untuk menyimpan hidrogen yang banyak, penjerapan hidrogen perlu dilakukan pada keadaan kriogenik. Di sini, magnesium oksida telah dicadangan sebagai pemangkin untuk meningkatkan prestasi nano-gentian karbon dalam penyimpanan hidrogen pada suhu bilik kerana ia adalah ringan dan berkebolehan untuk memisahkan molekul hidrogen. Komposit magnesium oksida nano-gentian karbon telah disediakan dengan polivinilpirolidon polimer dan magnesium oksida melalui kaedah elektroputaran. Sampel dicirikan dengan mikroskopi elektron pengimbasan pancaran medan, belauan sinar-X, spektroskopi inframerah transformasi Fourier, analisis termogravimetri, kalorimetri pengimbasan pembezaan dan mikrogravimetri. Zarah $\mathrm{MgO}$ terbentuk dipermukaan dan berada di dalam $\mathrm{MgO}-\mathrm{CNF}$ telah meningkatkan spesifik luas permukaan. $\mathrm{MgO}-\mathrm{CNF}$ dengan luas permukaan tentu $547 \mathrm{~m}^{2} / \mathrm{g}$, berkebolehan menyimpan hidrogen sebanyak $2.54 \mathrm{wt} . \%$ pada suhu bilik, yang mana peratus peningkatan kapasiti penyimpanan hidrogen melebihi $30 \%$ berbanding dengan menggunakan CNF sahaja.
\end{abstract}

Kata kunci: elektroputaran, penyimpanan hidrogen, nano-gentian karbon, oksida logam 


\section{Introduction}

In addition to their excellent thermal and chemical stabilities and fast adsorption kinetics [1], carbon nanomaterials, such as carbon nanofibres (CNFs) with a large specific surface area of up to $700 \mathrm{~m}^{2} / \mathrm{g}$, can adsorb hydrogen gas on the surface or in the pores [2]. Nonetheless, a reasonable hydrogen adsorption capacity of $>2 \mathrm{wt}$. \% $\mathrm{H}_{2}$ [3] can only be achieved at cryogenic temperature or at high pressure. The recent study of Yang et al. [4] have shown that at $77 \mathrm{~K}$ and 1 bar, the hydrogen uptake of multiwalled carbon nanotube is only 0.21 wt. $\% \mathrm{H}_{2}$. Meanwhile, the maximum hydrogen storage of CNF obtained by Jaybhaye et al. [5] and Bai et al. [6] are 0.65 and $0.6 \mathrm{wt}^{\circ} \% \mathrm{H}_{2}$ at $330 \mathrm{~K}$ and $9 \mathrm{MPa}$, respectively. Moreover, the amount of hydrogen absorption on all types of carbon materials at ambient temperature and pressure of up to 100 bars is less than $1.0 \mathrm{wt} \% \mathrm{H}_{2}$ [7-9]. Hence, several attempts, such as the use of production techniques [10,11], surface modification [12-14] and metal-doped materials [14-17] have been performed to enhance the hydrogen sorption of $\mathrm{C}$-based materials. To exhibit a microstructure with a high surface area-to-volume ratio, CNFs can be produced using chemical vapour deposition (CVD), plasma-enhanced, arc discharge methods and pulsed laser deposition $[10,18,19]$. However, these methods are costly and difficult to produce in large scale [20]. One of the options to synthesise carbon nanofibre via electrospinning technique [21] because it is a versatile technique to produce micro- and nanoscale nanofibres. The CNFs produced from electrospinning have a small diameter in ranging from $5 \mathrm{~nm}$ to $500 \mathrm{~nm}$ [22], resulting in a large specific surface area.

Surface modifications via physical and chemical activations improve the hydrogen storage capacity [23]. Physical activation involves the gasification of carbon materials in the presence of oxidizing agents, such as $\mathrm{CO}_{2}$ and steam. Meanwhile, chemical activation increases porosity via the chemical reactions between the reagents (KOH) and carbon materials. Chemical activation operates at a lower processing temperature and faster processing time, thereby producing higher porosity [23]. Activated carbon with a hydrogen storage capacity of $0.81 \mathrm{wt} . \% \mathrm{H}_{2}$ at $298 \mathrm{~K}$ and pressure of 100 bar was obtained by Kim et al. [24] after KOH activation. Nevertheless, a high specific surface area does not guarantee a high hydrogen storage capacity, especially at room temperature. Chen et al. [13] activated polyaniline-based carbon nanotubes with $\mathrm{KOH}$ and obtained a hydrogen storage capacity of 5.2 wt.\% $\mathrm{H}_{2}$ at a cryogenic temperature of $77 \mathrm{~K}$ and pressure of 50 bar. The chemical $\mathrm{KOH}$ activation of CNF was reported by Jiménez et al. [25], wherein the CNF adsorbed is 2.22 wt. $\% \mathrm{H}_{2}$ at $77 \mathrm{~K}$ and 10 bars. Nonetheless, storing hydrogen at cryogenic temperature is still less practical for an on-board hydrogen storage application. The presence of impurities, which reduces the hydrogen storage capacity [26], during the activation is also the main drawback of chemical activation.

Recently, researchers [27-30] have explored and investigated the use of metals on carbon nanomaterials to improve their ability to store more hydrogen at ambient temperature with low pressure. Metal and metal oxide such as $\mathrm{NiO}_{2}$, $\mathrm{TiO}_{2}, \mathrm{CuO}_{2}$ and $\mathrm{Pd}$ have been commonly used as an additive in CNFs to explore their catalytic effect in improving the hydrogen adsorption capability of CNFs at room temperature. For instance, Im et al. [31] have achieved 2.8 wt. $\% \mathrm{H}_{2}$ at 100 bars and at room temperature by adding copper in activated CNFs. This result suggested that metallic compound can enhance the hydrogen adsorption via the spill-over phenomenon [3, 5, 8]. Furthermore, the surface modification with metal will create metal hydride formation. The hydrogen molecules adsorbed on the metal are dissociated, followed by migration of hydrogen atom migration on the carbon materials [14]. Some of the hydrogen atoms form stable bonds with surface, leading to irreversible adsorption. Lachawiec et al. [32] also stated that other hydrogen atoms can be reversibly released by migration back to the metal particles in the form of hydride. The favourable hydrogen uptake of metal-doped carbon nanofiber can achieve $2.81 \mathrm{wt} \% \mathrm{H}_{2}$ at room temperature and at pressure of 70 bar [30].

In this work, magnesium-based material was chosen because of its light-weight characteristics, abundance and low cost as compared with $\mathrm{NiO}$ and $\mathrm{CuO}$ [33]. In addition, $\mathrm{MgO}$ has the catalytic ability to dissociate hydrogen molecules [34, 35], enabling it to possibly spill the hydrogen atom onto the carbon support. Hence, the combination of $\mathrm{MgO}$ and carbon nanofibre has a potential to improve the hydrogen storage capacity at room temperature with reduced pressure. 


\section{Materials}

\section{Materials and Methods}

Both $\mathrm{MgO}$ (nano-powder size of $<50 \mathrm{~nm}$ ) and polyvinylpyrrolidone (PVP) $\left(\mathrm{M}_{\mathrm{W}}=1,300,000 \mathrm{~g} / \mathrm{mol}\right.$ ) were purchased from Sigma-Aldrich. Absolute ethanol (99\%) was purchased from HmbG. All chemicals were used as received without further purification.

\section{Preparation of the MgO-CNF composite}

The precursor solution for electrospinning was prepared by mixing $7.50 \mathrm{~g} \mathrm{MgO}$ and $2.50 \mathrm{~g} \mathrm{PVP}$ in ethanol at $40{ }^{\circ} \mathrm{C}$. The solution was stirred with a magnetic stirrer for 4 hours to obtain a homogeneous solution. Then, the homogeneous solution was electrospun through a $20 \mathrm{~mL}$ syringe with a capillary tip size with diameter of $0.45 \mathrm{~mm}$, which was placed horizontally on an electrospinner (KSS Company), to produce the nanofibre composite mats. Electrospinning was performed at a voltage of $18 \mathrm{kV}$ and at $15 \mathrm{~cm}$ between the tip and the rotating drum that was covered with an aluminium foil. A syringe pump was used to control the flow rate of the solution at $1.5 \mathrm{~mL} / \mathrm{hours}$. The nanofibre composite was stabilised at $80{ }^{\circ} \mathrm{C}$ for 2 hours before it was carbonised at $800{ }^{\circ} \mathrm{C}$ for 2 hours in nitrogen gas to form $\mathrm{MgO}-\mathrm{CNFs}$.

\section{Characterization}

The morphology and surface structure of the samples were studied with a Supra 55VP field emission scanning electron microscope (FE-SEM). The nanofibres were sputter coated with platinum to increase their electrical conductivity. Average diameters of nanofibres were estimated by averaging 60 diameter measurements in the FESEM images. Energy dispersive spectroscopy (EDS) was used to map and identify the element distribution in the nanofibres.

Bruker-D8 Advance X-ray Diffractometer with a $\mathrm{Cu} K \alpha$ radiation source $(\lambda=0.154 \mathrm{~nm})$ was used to identify the phase compositions and the crystallinity of the samples. The X-ray diffraction (XRD) patterns were recorded in the scan range of $2 \theta$ from $10^{\circ}$ to $80^{\circ}$. To characterise the chemical bonding between $\mathrm{MgO}$ and PVP, we obtained the FTIR spectra by using NICOLET-380. The measurements were obtained in the range of $4000 \mathrm{~cm}^{-1}$ to $400 \mathrm{~cm}^{-1}$.

A STA 449 F3 Netzch Thermogravimetric Analyser (TGA) equipped with differential scanning calorimetry (DSC) was used to study the thermal stability and the different rates of energy in the endothermic (uptake heat) and exothermic (release heat) conditions. The samples were heated from room temperature to $700{ }^{\circ} \mathrm{C}$ at a heating rate of $10^{\circ} \mathrm{C} / \mathrm{min}$ under a continuous nitrogen flow.

The pressure-composition isotherm (PCI) hydrogen sorption was studied with a Cahn Thermax 500 microgravimetric balance with sensitivity of $1 \mu \mathrm{g}$ at $298 \mathrm{~K}$. A pressure sensor $(0-6.9 \mathrm{MPa})$ was used to measure the hydrogen pressure in the chamber. All samples were tested for their hydrogen storage from $0.1 \mathrm{MPa}$ to $5.0 \mathrm{MPa}$ at room temperature. Before the measurement, the samples were outgassed overnight until they reach a constant mass. The whole system was purged with Ar gas, which flowed through a molecular sieve and a cold trap to remove moisture and any impure substances. Hydrogen was charged step-wise, and the data were recorded when the mass reaches equilibrium. Hydrogen uptake was calculated after the buoyancy correction of the experiment.

\section{Results and Discussion}

The surface morphologies of both the PVP-CNF and $\mathrm{MgO}-\mathrm{CNF}$ composites are illustrated in Figure 1. The surface of PVP-CNFs (Figure 1a) was smooth and bead-free as compared with that of the MgO-CNF composite (Figure 1b). The morphology of the as-received $\mathrm{MgO}$ with irregular sphere particles is shown in Figure 1c. The incorporation of $\mathrm{MgO}$ in the precursor solution had a significant influence on the surface morphology of the CNF composite. The $\mathrm{MgO}-\mathrm{CNF}$ composite was rough with particles forming on the surface and entrapping inside the nanofibres. The diameter of PVP-CNFs was $481 \mathrm{~nm}$, with a specific surface area of $413 \mathrm{~m}^{2} / \mathrm{g}$. Meanwhile, the diameter of the $\mathrm{MgO}-\mathrm{CNF}$ composite was irregular with an average of $459 \mathrm{~nm}$ and specific surface area of $547 \mathrm{~m}^{2} / \mathrm{g}$. As shown in Figure 1c, the as-received $\mathrm{MgO}$ particles with an average particle size of $27.4 \pm 2.6 \mathrm{~nm}$ were agglomerated because of the high surface activity, as suggested by Ferari et al. [36]. The average particle size of the as-received $\mathrm{MgO}$ particles agrees with the average particle size of the $\mathrm{MgO}$ nanofibre composite of $25.3 \pm 4.8 \mathrm{~nm}$. 

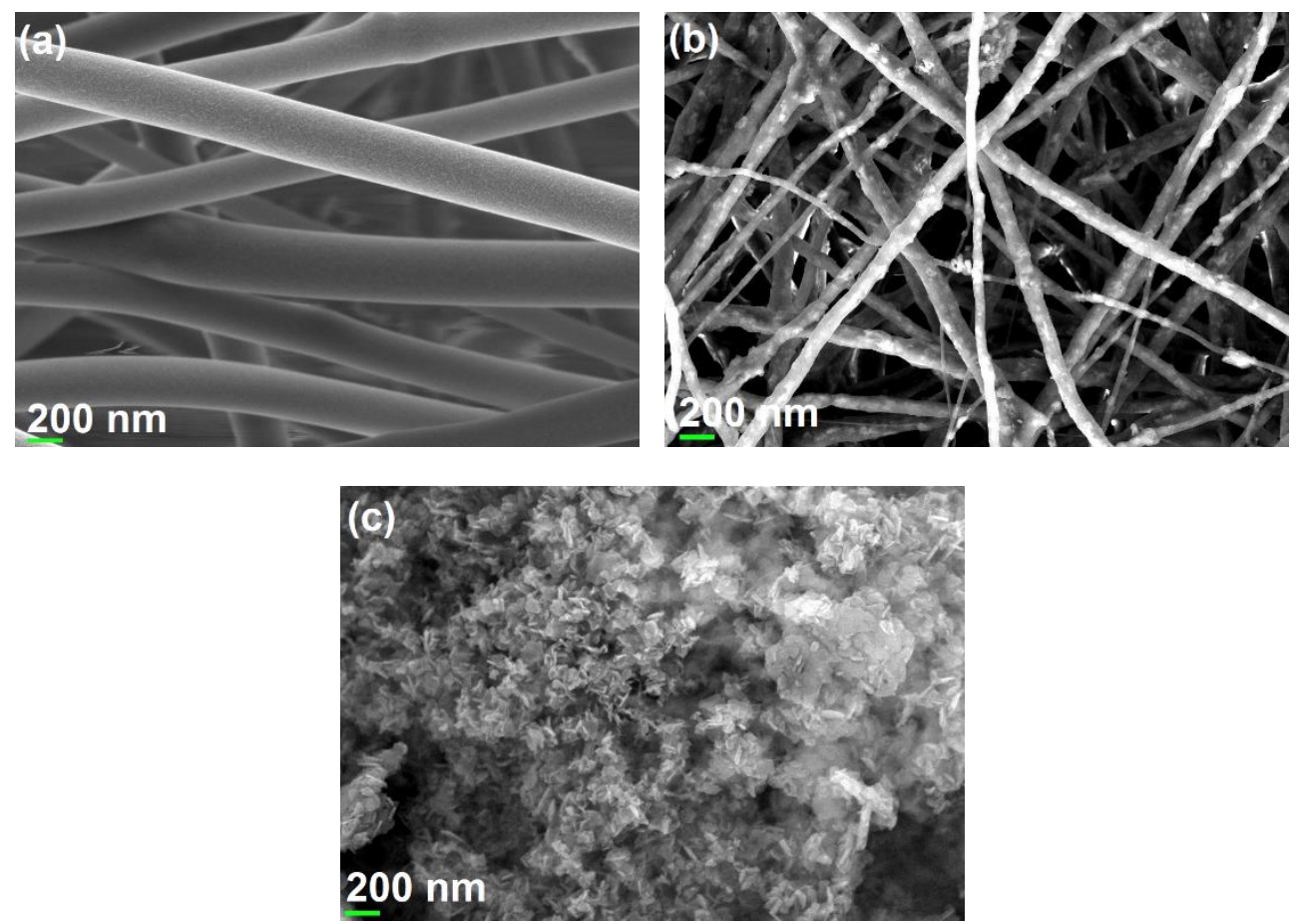

Figure 1. Field emission scanning electron microscope (FE-SEM) images of (a) the PVP-CNFs (b) MgO-CNF composite and (c) as-received $\mathrm{MgO}$

EDS mapping was used to identify the elements in the CNF composite, as shown in Figure 2. The colour intensity of EDS mapping is associated with the concentration of elements in nanofibres; the higher the intensity, the higher the concentration and vice versa. The carbon element was uniformly distributed on the nanofibre, indicating that most of the other elements are embedded inside the CNFs. Meanwhile, high Mg concentration was detected at different areas of CNFs, corresponding to the particle-like bright spots (circle) in the SEM image. The results confirmed the presence of $\mathrm{Mg}$ compound in the CNFs.
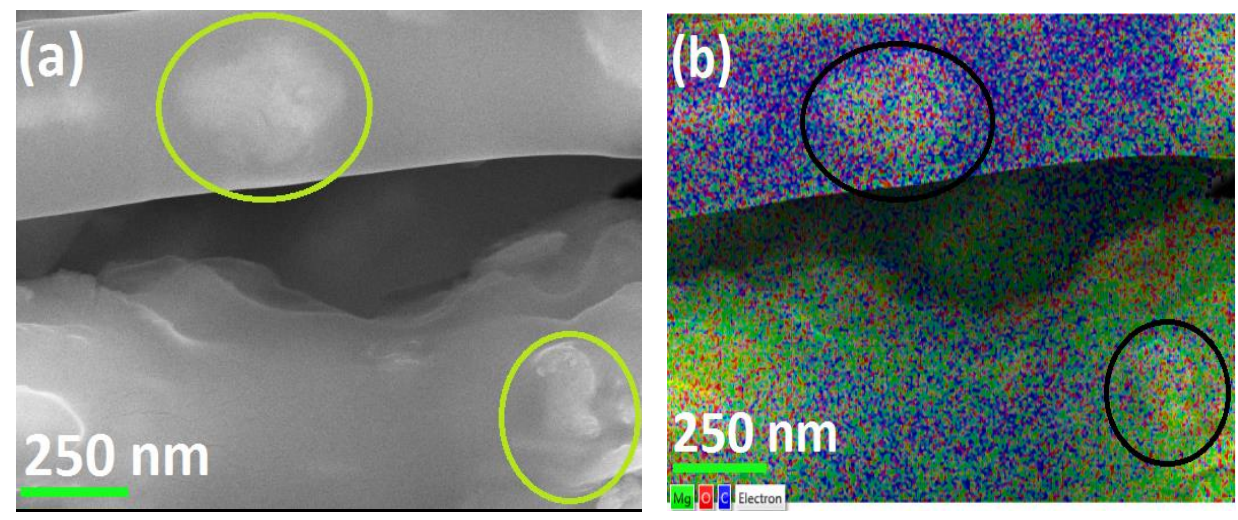

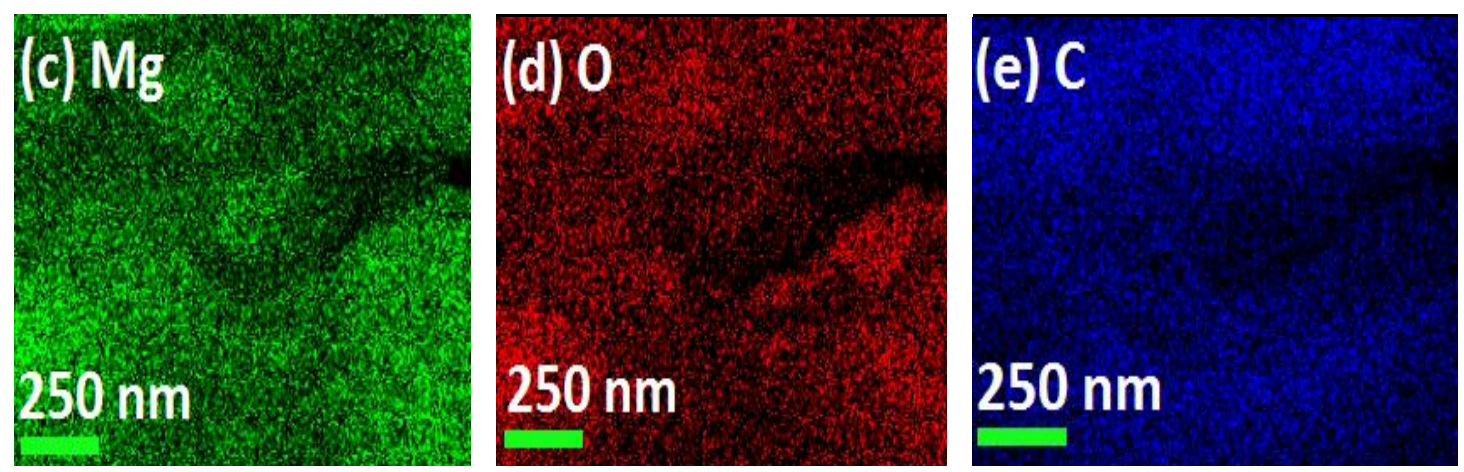

Figure 2. (a) Field emission scanning electron microscope (FE-SEM) image of the MgO-CNF composite. EDS mapping for (b) MgO-CNF composite, (c) Mg element, (d) $\mathrm{O}$ element and (e) $\mathrm{C}$ element

The XRD patterns of the PVP-CNFs, as-received $\mathrm{MgO}$ and $\mathrm{MgO}-\mathrm{CNF}$ composite are presented in Figure 3. As shown in Figure 3a, two broad peaks are observed at $11^{\circ}$ and $22^{\circ}$, which are induced by the PVP polymer. Both peak positions are similar with the results of Wang et al. [37] and Sivaiah et al. [38]. The broad peaks indicate that the CNFs have an amorphous phase. $\mathrm{MgO}$ peaks in Figure $3 \mathrm{~b}$ were observed at the $2 \theta$ values of $37.1^{\circ}, 43.1^{\circ}, 62.5^{\circ}$, $74.6^{\circ}$ and $78.6^{\circ}$, corresponding to the (111), (200), (202), (311) and (222) planes, respectively. All diffraction peaks were sharp, indicating that the $\mathrm{MgO}$ particles are crystalline $[39,40]$. Additional peaks were observed at the $2 \theta$ values of $38.02^{\circ}$ and $58.62^{\circ}$, belonging to the secondary $\mathrm{Mg}(\mathrm{OH})_{2}$ phase. These peak positions at the $2 \theta$ values of $38.02^{\circ}$ and $58.62^{\circ}$ correspond to the crystal (101) and (110) planes, respectively [41]. The formation of $\mathrm{Mg}(\mathrm{OH})_{2}$ was likely caused by the hydration of $\mathrm{MgO}$ upon exposure to humidity [42], where $\mathrm{Mg}^{2+}$ and $\mathrm{OH}^{-}$were diffused into a layer of chemically and physically adsorbed water, forming and growing into a $\mathrm{Mg}(\mathrm{OH})_{2}$ crystal.

The XRD pattern of the MgO-CNF composite nanofibre is presented in Figure 3c. The pattern of the composite was a combination of Figures $3 \mathrm{a}$ and $\mathrm{b}$, with no detected additional peaks, indicating that the $\mathrm{Mg}$ compounds are stable with CNFs. However, peaks belonging to $\mathrm{MgO}$ in Figure $3 \mathrm{c}$ slightly shifted to the lower angle as compared with the $\mathrm{MgO}$ phase in Figure 3b, suggesting that $\mathrm{MgO}$ may experience tensile residue stress caused by the pulling effect during the formation of nanofibres in the electrospinning process.

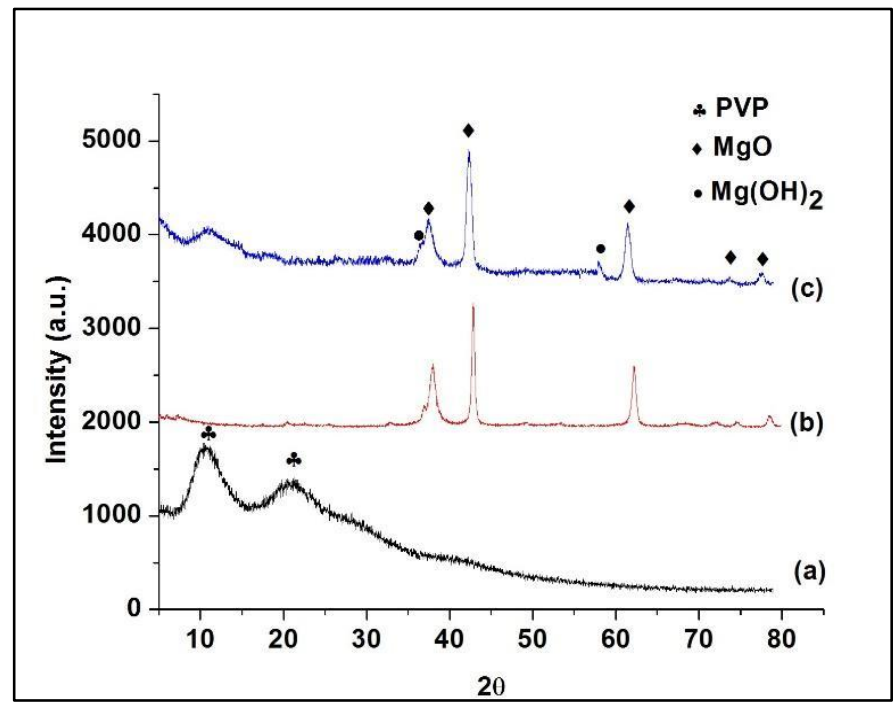

Figure 3. XRD patterns of (a) $\mathrm{PVP}-\mathrm{CNFs}$ (b) as-received $\mathrm{MgO}$ and (c) $\mathrm{MgO}-\mathrm{CNF}$ composite 
FTIR was used to identify chemical bonding in the nanofibre composite. Figure 4 reveals the FTIR spectrum of the PVP nanofibre, PVP-CNFs, as-received $\mathrm{MgO}$ and $\mathrm{MgO}-\mathrm{CNF}$ composite. Compared with the results of Baytak et al. [43], the PVP nanofibre spectrum had four main sharp peaks at $1659,1463,1421$ and $1289 \mathrm{~cm}^{-1}$ in the present study. The peak at $1659 \mathrm{~cm}^{-1}$ is related to the stretching vibration of $\mathrm{C}=\mathrm{O}$. Meanwhile, the peak at 1463 and $1421 \mathrm{~cm}^{-1}$ are ascribed to the vibration bending and vibration deformation of methylene $\left(\mathrm{CH}_{2}\right) \mathrm{N}$-vinylpyrrolidone in the PVP chain, respectively. Another peak at $1289 \mathrm{~cm}^{-1}$ belongs to the stretching vibration of $\mathrm{C}-\mathrm{N}$. Other broad absorption peaks at 3420 and $2954 \mathrm{~cm}^{-1}$ are ascribed to the vibration bonding of $\mathrm{O}-\mathrm{H}$ and the stretching vibration of $\mathrm{C}-\mathrm{H}$ (methylene group), respectively [44]. All these peaks indicate the presence of PVP polymer in the nanofibre, which is consistent with the results of Dong et al. [45], Rafizah et al. [44] and Saravanan et al. [46]. After carbonization (Figure 4b), no significant characteristic peaks were observed, which confirms that only $\mathrm{C}$ atoms are present in the PVP-CNFs. These results are similar to the findings of Zhou et al. [47] and Guadagno et al. [48].

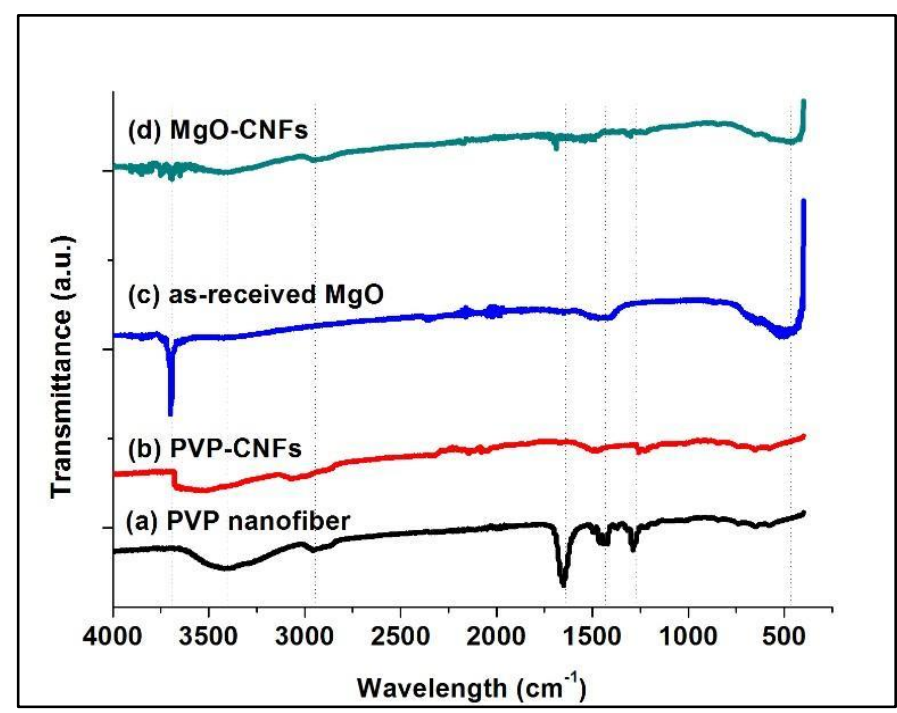

Figure 4. FTIR peak of (a) PVP nanofibre, (b) PVP-CNFs, (c) as-received MgO and (d) MgO-CNF composite

For as-received $\mathrm{MgO}$, the $\mathrm{MgO}$ absorption peak was located at $490 \mathrm{~cm}^{-1}$, which is similar with the results of Razaei et al. [25]. However, in the range of $4000-2500 \mathrm{~cm}^{-1}$, a strong peak was detected at $3750 \mathrm{~cm}^{-1}$. This peak was assigned to the isolated $\mathrm{Mg}-\mathrm{OH}$ group. The presence of bending vibration of the $\mathrm{O}-\mathrm{H}$ group is correlated to the exposure of the as-received $\mathrm{MgO}$ sample to humidity [51]. These results correspond to the observations in the XRD results. The FTIR spectra of MgO-CNFs were the superimposed FTIR spectra of both $\mathrm{MgO}$ and PVP-CNF. All functional groups and bonds corresponded well to their respective components, except that the transmittance signal of the $\mathrm{Mg}-\mathrm{OH}$ group at $3750 \mathrm{~cm}^{-1}$ was less pronounced. This result indicates that the CNFs have changed the polarity of the $\mathrm{Mg}-\mathrm{OH}$ bond.

The mass changes and thermal stability of the $\mathrm{MgO}-\mathrm{CNF}$ composite are compared with those of the as-received $\mathrm{MgO}$ and PVP-CNFs, as shown in Figure 5. For TGA, a significant weight loss of the as-received $\mathrm{MgO}, \mathrm{PVP}-$ $\mathrm{CNFs}$ and $\mathrm{MgO}-\mathrm{CNF}$ composite can be observed at different temperatures as the temperature increases from room temperature to $700{ }^{\circ} \mathrm{C}$. Meanwhile, the DSC graph shows multiple endothermic peaks (negative peak, releases heat). For PVP-CNFs, $5.2 \%$ weight loss was observed in the TGA curve between $25^{\circ} \mathrm{C}$ to $166^{\circ} \mathrm{C}$, corresponding to a strong endothermic peak at $126{ }^{\circ} \mathrm{C}$. The initial weight loss at temperature of less than $150{ }^{\circ} \mathrm{C}$ was due to the evaporation of solvent and any moisture from the nanofibre. This result is similar to the findings of Kim et al. [52] and Sales et al. [53]. At the temperature range from $373{ }^{\circ} \mathrm{C}$ to $466{ }^{\circ} \mathrm{C}$, another significant weight loss of $71.5 \%$ was detected in the graph, which is associated with the thermal decomposition of the main chain PVP polymer [52]. Corresponding to the weight loss, an endothermic peak was also detected in the DSC graph at $449{ }^{\circ} \mathrm{C}$. Beyond 500 ${ }^{\circ} \mathrm{C}$, the PVP was decomposed completely, and a constant weight was obtained. 


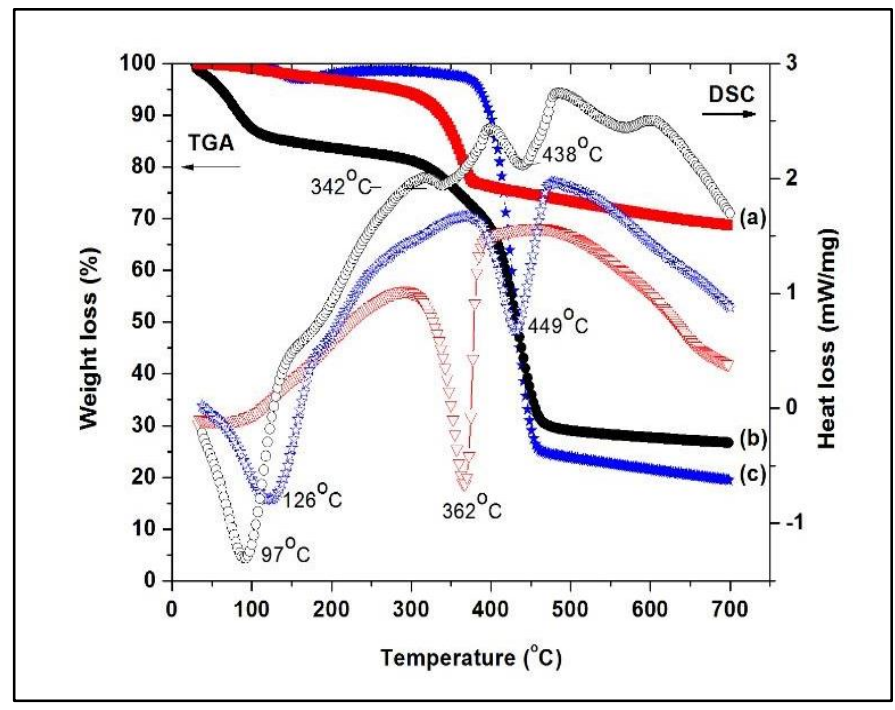

Figure 5. TGA-DSC graph of the (a) as-received $\mathrm{MgO}(\boldsymbol{\nabla})$ (b) $\mathrm{MgO}-\mathrm{CNF}$ composite ( $\square$ ) and (c) PVP-CNFs ( $\star$ ). TGA: close symbol, DSC: open symbol

The as-received $\mathrm{MgO}$ showed a small weight loss of $0.98 \%$ between $52{ }^{\circ} \mathrm{C}$ to $311^{\circ} \mathrm{C}$. Similar to the results of PVP$\mathrm{CNFs}$, the first weight loss was related to evaporation of moisture that was trapped on the sample. A significant weight loss occurred at the temperature range from $326{ }^{\circ} \mathrm{C}$ to $374{ }^{\circ} \mathrm{C}$, corresponding to an endothermic peak at 362 ${ }^{\circ} \mathrm{C}$. This weight loss is associated to the decomposition of $\mathrm{Mg}(\mathrm{OH})_{2}$ [54], which is an impure compound that was detected in the XRD results. As the temperature increased above $400{ }^{\circ} \mathrm{C}$, the weight of the as-received $\mathrm{MgO}$ was continuously reduced. This result is associated with the transformation from the amorphous to crystalline phase of $\mathrm{MgO}[55]$.

The presence of $\mathrm{MgO}$ in the CNFs had affected the thermal stability of PVP. Similar to the two other samples, the first weight loss of $14.03 \%$ accompanied a strong endothermic peak at $92{ }^{\circ} \mathrm{C}$ was caused by the loss of solvent and moisture from the nanofibre composite. The second weight loss of $56.22 \%$ occurred between $278{ }^{\circ} \mathrm{C}$ and $488{ }^{\circ} \mathrm{C}$ was similar to the decomposition of PVP-CNFs and MgO, corresponding to two DSC peaks, that is, two broad endothermic peaks at $342{ }^{\circ} \mathrm{C}$ and $438{ }^{\circ} \mathrm{C}$. Both peaks shifted to a lower temperature as compared with its respective components. This result suggests that the addition of $\mathrm{MgO}$ lowers the decomposition activation energy of the $\mathrm{MgO}-$ CNF composite, as shown in the Kissinger analysis below.

Kissinger's equation [56] was used to estimate the decomposition activation energy of the MgO-CNF composite. The logarithm of heating rates $\left(\beta=5{ }^{\circ} \mathrm{C} / \mathrm{min}, 10^{\circ} \mathrm{C} / \mathrm{min}\right.$ and $\left.15^{\circ} \mathrm{C} / \mathrm{min}\right)$ has a linear inverse relationship with the maximum desorption temperature at each heating rate according to the equation 1below:

$$
\ln \left[\beta / T_{\max }{ }^{2}\right]=-E_{A} / R T_{\max }+A
$$

where $\beta$ is the heating rate, $T_{\max }$ is the maximum peak in the DSC curve, $R$ is the gas constant and $A$ is the linear constant. The activation energy was calculated from the slopes of $\ln \left[\beta / T_{\max }{ }^{2}\right]$ versus $1000 / T_{\max }$, as plotted in Figure 6. As shown in the figure, the incorporation of $\mathrm{MgO}$ into CNFs has lowered the decomposition activation energy of $\mathrm{MgO}$ from $191.53 \mathrm{~kJ} / \mathrm{mol}$ to $182.68 \mathrm{~kJ} / \mathrm{mol}$. 


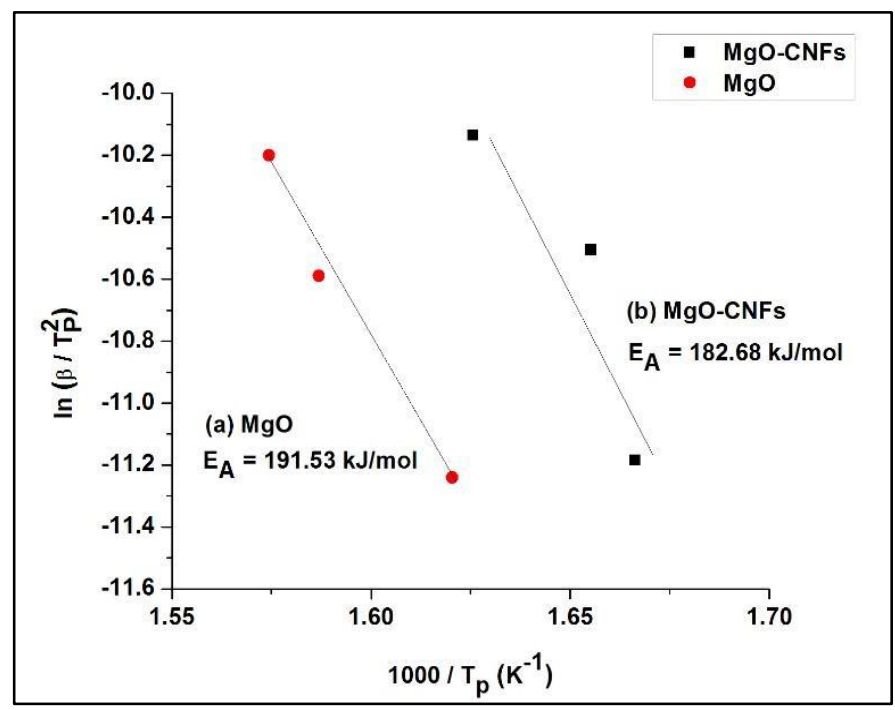

Figure 6. Kissinger's plot of the (a) as-received $\mathrm{MgO}$ and (b) $\mathrm{MgO}-\mathrm{CNFs}$

Figure 7 shows the hydrogen storage capacity of PVP-CNFs, as-received $\mathrm{MgO}$ and $\mathrm{MgO}-\mathrm{CNF}$ composite at room temperature. $\mathrm{PVP}-\mathrm{CNFs}$, as-received $\mathrm{MgO}$ and $\mathrm{MgO}-\mathrm{CNFs}$ adsorbed 1.90, 2.08 and 2.54 wt.\% of hydrogen at $5.0 \mathrm{MPa}$ and room temperature, respectively. With the addition of $75 \%$ of $\mathrm{MgO}$ in the CNFs, the hydrogen sorption capacity of CNFs was increased by approximately $30 \%$, and the composite capacity was much higher than that of the as-received $\mathrm{MgO}$. This improvement indicates that $\mathrm{MgO}$ has a synergetic effect in enhancing the sorption capacity because of a few possible reasons. Firstly, the rough surface morphology of the $\mathrm{MgO}-\mathrm{CNF}$ composite increases the specific surface area, which provides more sites to adsorb the hydrogen. Secondly, $\mathrm{MgO}$, which is distributed in the form of a single particle in CNFs homogenously in the composite, has effectively enhanced the hydrogen contact surface of $\mathrm{MgO}$ as compared with that of the as-received $\mathrm{MgO}$, which tends to agglomerate. Lastly, the catalytic characteristics of metal oxide may reduce the adsorption activation energy and promote spillover effect, as suggested by Yaakob et al. [30], who observed a similar improvement by using $\mathrm{ZnO}$ nanoparticles.

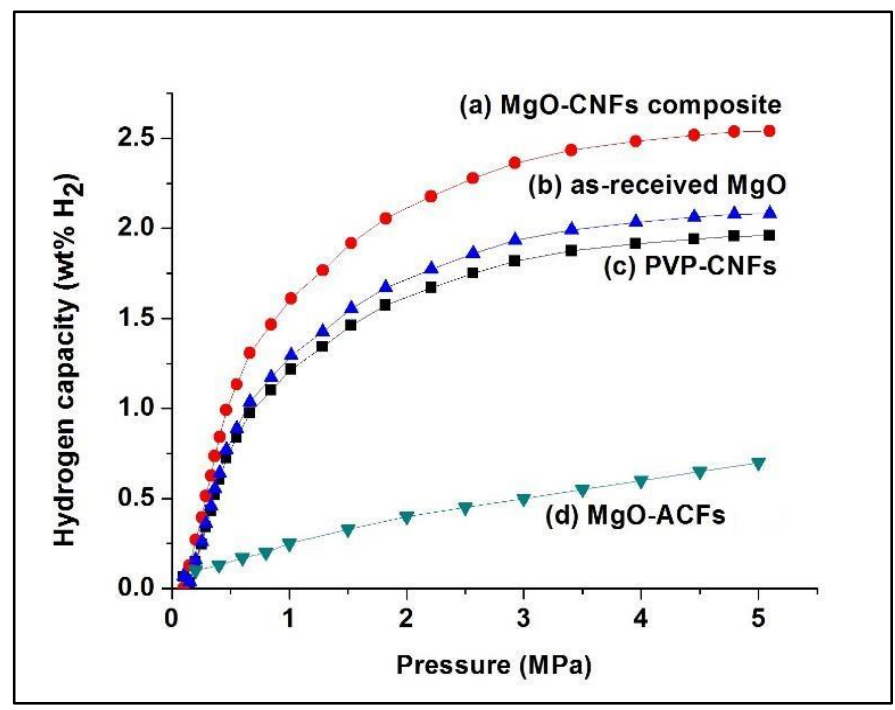

Figure 7. Pressure-composition isotherm of (a) $\mathrm{MgO}-\mathrm{CNF}$ composite, (b) as-received $\mathrm{MgO}$, (c) PVP-CNFs and (d) $\mathrm{MgO}-\mathrm{ACFs}[31]$ at room temperature 
The hydrogen sorption capacity of this work surpassed the findings of Im et al. [31], of which the $\mathrm{MgO}$-activated polyacrylonitrile $\mathrm{C}$ fibres (MgO-ACFs) only adsorbed $0.7 \mathrm{wt} . \% \mathrm{H}_{2}$ at $5.0 \mathrm{MPa}$ although the specific surface area of $\mathrm{MgO}-\mathrm{ACF}$ was up to twofold of that of this work. In this case, the role of $\mathrm{MgO}$ as a catalyst was suppressed probably because no $\mathrm{MgO}$ particles were exposed on the surface of ACFs, as indicated by the findings of Im et al. [3]. Presumably, the $\mathrm{MgO}$ particles on the surface have been removed during the chemical activation and washing process. Comparing the results, we can postulate that the position of $\mathrm{MgO}$ particles in the CNFs is of utmost importance to fully exploit the potential of metal oxide.

\section{Conclusion}

The $\mathrm{MgO}-\mathrm{CNF}$ composite has been successfully synthesised using the electrospinning method. The addition of $\mathrm{MgO}$ in $\mathrm{CNFs}$ has increased the specific surface area of CNFs, which provides more hydrogen adsorption site and subsequently improves the hydrogen storage capacity. Nonetheless, the catalytic effect of $\mathrm{MgO}$ that promotes the spill-over mechanism has a larger role in enhancing the hydrogen storage capacity. Therefore, $\mathrm{MgO}$ must be located on the surface of CNFs to take advantage of its catalytic characteristics. This work has successfully improved the maximum hydrogen storage capacity of PVP-CNFs by more than $30 \%(2.54 \mathrm{wt} \%)$ at $5.0 \mathrm{MPa}$ and at room temperature as compared with that of PVP-CNFs alone.

\section{Acknowledgement}

The authors would like to acknowledge the financial support given by the Universiti Kebangsaan Malaysia (DIP2014-011, GGPM-2016-054) and Malaysian Ministry of Higher Education (FRGS/2/2014/ST05/UKM/03/1).

\section{References}

1. Raza, A., Wang, J., Yang, S., Si, Y. and Ding, B. (2014). Hierarchical porous carbon nanofibers via electrospinning. Carbon Letters, 15:1-14.

2. Ströbel, R., Garche, J., Moseley, P. T., Jörissen, L. and Wolf, G. (2006). Hydrogen storage by carbon materials. Journal of Power Sources, 159: $781-801$.

3. Zubizarreta, L., Gome, E. I., Arenillas, Z., Ania, C. O., Parra, J. B. and Pis, J.J. (2008). $\mathrm{H}_{2}$ storage in carbon materials. Adsorption, 14: 557 - 566.

4. Yang, S. J., Cho, J. H., Nahm, K. S. and Park, C. R. (2010). Enhanced hydrogen storage capacity of Pt-loaded CNT@MOF-5 hybrid composites. International Journal of Hydrogen Energy, 35: 13062 - 13067.

5. Jaybhaye, S., Sharon, M., Sharon, M., Sathiyamoorthy, D. and Dasgupta, K. (2006). Semiconducting carbon nanofibers and hydrogen storage. Synthesis and Reactivity in Inorganic, Metal-Organic, and Nano-Metal Chemistry, 37(6): 2007.

6. Bai, B. C, Kim, G. J., Naik, M. and Lee, Y.-S. (2011). The hydrogen storage capacity of metal-containing polyacrylonitrile-based electrospun carbon nanofibers. Carbon Letters, 12: 171 - 176.

7. Yurum, Y., Taralp, A. and Nejat Veziroglu, T. (2009). Storage of hydrogen in nanostructured carbon materials. International Journal of Hydrogen Energy, 34: 3784 - 3798.

8. Collin, D. J. and Zhou, H.-C. (2007). Hydrogen storage in metal-organic frameworks. Journal of Materials Chemistry, 17: 3154 - 3160.

9. Vasiliev, L. L., Kanonchik, L. E., Kulakov, A. G., and Babenko, V. A. (2007). Hydrogen storage system based on novel carbon materials and heat pipe heat exchanger. International Journal of Thermal Sciences, 46: 914 925.

10. Sami, A. and Hussein, A. (2015). Growth of carbon nanofibers synthesised from decomposition of liquid organic waste on a $\mathrm{Ni} / \mathrm{Al}_{2} \mathrm{O}_{3}$ catalyst: Themodynamic and kinetic analyses. Energy Procedia, 74: 32 - 43.

11. Kvande, I., Chen, D., Yu, Z., Ronning, M. and Holmen, A. (2007). Optimization and scale-up of CNF prodcution based on intrinsic kinetic data obtained from TEOM. Journal of Catalyst, 256: $204-214$.

12. Wang, J. and Kaskel, S. (2012). KOH activation of carbon-based materials for energy storage. Journal of Materials Chemistry, 22: 23710 - 23725.

13. Chen, Y., Zhu, H. and Liu, Y. (2011). Preparation of activated rectangular polyaniline-based carbon tubes and their application in hydogen adsorption. International Journal of Hydrogen Energy, 36: 11738 - 11745.

14. Kim, H., Lee, D. and Moon, J. (2011). Co-electrospun Pd-coated porous carbon nanofibers for hydrogen storage applications. International Journal of Hydrogen Energy, 36: 3566 - 3573. 
15. Im, J. S., Kwon, O., Kim, Y. H., Park, S.-J. and Lee, Y.-S. (2008). The effect of embedded vanadium catalyst on activated electrospun CFs for hydrogen storage. Microporous Mesoporous Materials, 115: 514 - 521.

16. Froudakis, G.E. (2011). Hydrogen storage in nanotubes \& nanostructures. Materials Today, 14: 324 - 328.

17. Konda, S. K. and Chen, A. (2016). Palladium based nanomaterials for enhanced hydrogen storage spillover and storage. Materials Today, 19: 100 - 108.

18. Manafi, S. A. and Badiee, S. H. (2008). Production of carbon nanofibers using a CVD method with lithium fluoride as a supported cobalt catalyst. Research Letters in Materials Science, 2008: $1-5$.

19. Mitra, S., Sridharan, K., Unnam, J. and Ghosh, K. (2008). Synthesis of nanometal oxide and nanometals using hot-wire and thermal CVD. Thin Solid Films, 516: $798-802$.

20. Rafique, M. M. A. and Iqbal, J. (2011). Production of carbon nanotubes by different routes - A review. Journal of Encapsulation and Adsorption, 1:29 - 34.

21. Su, Z., Ding, J. and Wei, G. (2014). Electrospinning: A facile technique for fabricating polymeric nanofibers doped with carbon nanotubes and metallic nanoparticles for sensor applications. Royal Society of Chemistry, 4: $52598-52610$.

22. Kunowsky, M., Marco-Lózar, J. P., Oya, A. and Linares-Solano, A. (2012). Hydrogen storage in $\mathrm{CO}_{2}$-activated amoprhous nanofibers and their monoliths. Carbon, 50: 1407 - 1416.

23. Yang, S. J., Jung, H., Kim, T. and Park, C. R. (2012). Recent advances in hydrogen storage technologies based on nanoporous carbon materials. Progress in Natural Science: Materials International, 22: 631 - 638.

24. Kim, B. J., Lee, Y. S. and Park, S. J. (2008). Novel porous carbons synthesized from polymeric precursors for hydrogen storage. International Journal of Hydrogen Energy, 33: 2254 - 2259.

25. Jiménez, V., Ramírez-Lucas, A., Sanchéz, P., Valverde, J. L. and Romero, A. (2012). Hydrogen storage in different carbon materials: Influence of the porosity development by chemical activation. Applied Surface Science, 258: 2498 - 2509.

26. Sawai, N. U. and Harun, F. W. (2015). Hydrogen adsoprtion on agricultural-based activated carbons, zeolite templated-carbons and clay-based materials: A review. Journal of Industrial \& Engineering Chemistry Research, 1: $1-7$.

27. Jia, M. and Zhang, Y. (2009). Study on the synthesis of carbon fibers and CNF using potassium iodide catalyst. Materials Letters, 63: 2111 - 2114.

28. Sundaramurthy, J., Li, N., Kumar, P. S. and Ramakrishna, S. (2014). Perspective of electrospun nanofibers in energy and environment. Biofuel Research Journal, 2: $44-54$.

29. Lim, K. L., Kazemian, H., Yaakob, Z. and Daud, W. R. W. (2010). Solid-state materials and methods for hydrogen storage: A critical review. Chemical Engineering \& Technology, 33: 213 - 226.

30. Yaakob, Z., Khaadem, D. J., Shahgaldi, S., Daud, W. R. W. and Tasirin, S. M. (2012). The role of Al and Mg in the hydrogen storage of electrospun $\mathrm{ZnO}$ nanofibers. International Journal of Hydrogen Energy, 37: 8388 8394.

31. Im, J. S., Park, S. J., Kim, T. and Lee, Y. S. (2009). Hydrogen storage evaluation based on investigations of the catalytic properties of metal/metal oxides in electrospun carbon fibers. International Journal of Hydrogen Energy, 34: $3382-3388$.

32. Lachawiec, A. J., Qi, J. G. and Yang, R. T. (2005). Hydrogen storage in nanostructured carbons by spillover: Bridge-building enhancement. Langmuir, 21: 11418 - 11424.

33. Campbell, F. C. (2012). Introduction and uses of lightweight materials. Lightweight materials - understanding the basics. ASM International, 1-31.

34. Ito, T., Sekino, T., Moriai, N. and Tokuda, T. (1981). Hydrogen adsorption on magnesium oxide powders. Journal of the Chemical Society, Faraday Transactions, 1(77): 2181 - 2192.

35. Wu, G., Zhang, J., Wu, Y., Li, Q., Chou, K. and Bao, X. (2009). Adsorption and dissociation of hydrogen on $\mathrm{MgO}$ surface: A first-principles study. Journal of Alloys and Compounds, 480: 788 - 793.

36. Ferrari, B., Moreno, R., Sarkar, P. and Nicholson, P. S. (200). Electrophoretic deposition of MgO from organic suspensions. Journal of European Ceramic Society, 20: 99 - 106.

37. Wang, C., Ma, C., Wu, Z., Liang, H., Yan, P., Song, J., Ma, N. and Zhao, Q. (2015). Enhanced bioavailability and anticancer effect of curcumin-loaded electrospun nanofiber: In vitro and in vivo study. Nanoscale Research Letters, 10: 439.

38. Sivaiah, K., Kumar, K. N., Naresh, V. and Buddhudu, S. (2011). Structural and optical properties of $\mathrm{Li}^{+}: \mathrm{PVP} \&$ $\mathrm{Ag}^{+}:$PVP polymer films. Materials Sciences and Applications, 2: $1688-1696$. 
39. Tamilselvi, P., Yelilarasi, A., Hema, M. and Anbarasan, R. (2013). Synthesis of hierarchical structured MgO .by sol-gel method. Nano Bulletin, 2: 1301061 - 1301065.

40. Aykut, Y. (2013). Electrospun MgO-loaded carbon nanofibers: Enhanced field electron emission from the fibers in vacuum. Journal of Physics and Chemistry Solids, 74: 328 - 337.

41. Dhaouadi, H., Chaabane, H. and Touati, F. (2011). $\mathrm{Mg}(\mathrm{OH})_{2}$ nanorods synthesized by a facile hydrothermal method in the presence of CTAB. Nano-Micro Letters, 3: 153-159.

42. Salamão, R. and Pandolfelli, V. C. (2008). Magnesia sinter hydration-dehydration behavior in refractory castables. Ceramic International, 34: 1829 - 1834.

43. Baytak, A. K., Duzmen, S., Teker, T. and Aslanoglu, M. (2017). Voltammetric determination of methylparaben and its DNA interaction using a novel platform based on carbon nanofibers and cobalt-nickel-palladium nanoparticles. Sensors Actuators B, 239: 330 - 337.

44. Rafizah, W. A. W. and Ismail, A. F. (2008). Effect of carbon molecular sieve sizing with poly(vinylpyrrolidone) K-15 on carbon molecular sieve-polysulfone mixed matrix membrane. Journal of Membrane Science, 307: 53 - 61.

45. Dong, G., Xiao, X., Liu, X., Qian B., Ma, Z., Ye, S., Chen, D. and Qiu, J. (2010). Preparation and characterization of $\mathrm{Ag}$ nanoparticle embedded polymer electrospun nanofibers. Journal of Nanoparticle Research, 12: 1319 - 1329.

46. Saravanan, L., Diwakar, S., Mohankumar, R., Pandurangan, A. and Jayavel, R. (2011). Synthesis, structural and optical properties of PVP encapsulated CdS nanoparticles. Nanomaterials and Nanotechnology, 1: $42-48$.

47. Zhou, C., Liu, Z., Du, X., Mitchell, D. R. G., Mai, Y.-W., Yan, Y. and Ringer, S. (2012). Hollow nitrogencontaining core/shell fibrous carbon nanomaterials as support to platinum nanocatalysts and their TEM tomography study. Nanoscale Reserach Letters, 7(165): 1 - 11.

48. Guadagno, L., Raimondo, M., Vittoria, V., Vertuccio, L., Lafdi, K., Vivo, B. D., Lamberti, P., Spinelli, G. and Tucci, V. (2013). The role of carbon nanofiber defects on the electrical and mechanical properties of CNFbased resins. Nanotechnology, 24: $1-10$.

49. Shao, C., Guan, H. and Liu, Y. (2006). MgO nanofibers via electrospinning technique. Journal of Materials Science, 41: $3821-3824$.

50. Rezaei, M., Khajenoori, M. and Nematollahi, B. (2011). Synthesis of high surface area nanocrystalline $\mathrm{MgO}$ by pluronic P123 triblock copolymer surfactant. Powder Technology, 205: 112 - 116.

51. Sutcu, M., Akkrut, S. and Oku, S. (2010). Microstructural study of surface hydration on magnesia refractory. Ceramics International, 36: 1731 - 1735.

52. Kim, J.-H., Yoo, S.-J., Kwak, D.-H., Jung, H.-J., Kim, T.-Y., Park, K.-H., and Lee, J.-W. (2014). Characterization and application of electrospun alumina nanofibers. Nanoscale Research Letters, 9: 1 - 6.

53. Salles, T. H. C., Lombello, C. B and D’Ávila, M. A. (2015). Electrospinning of gelatin/poly(vinylpyrrolidone) blends from water/acetic acid solutions. Materials Research, 18: $509-518$.

54. Behij, S., Hammi, H., Hamzaoui, A. H. and M'nif, A. (2013). Magnesium salts as compounds of the preparation of magnesium oxide from tunisian natural brines. Chemical Industry and Chemical Engineering Quarterly, 19: $263-271$.

55. Mastuli, M. S., Ansari, N. S., Nawawi, M. A. and Mahat, A. M. (2012). Effects of cationic surfactant in sol-gel synthesis of nano sized magnesium oxide. APCBEE Procedia, 3: 93 - 98.

56. Kissinger, H. E. (1957). Reaction kinetics in differential thermal analysis. Analytical Chemistry, 29: 1702 1706. 